\title{
Water, not food, contributes the majority of strontium and barium deposited in the otoliths of a marine fish
}

\author{
B. D. Walther*, S. R. Thorrold \\ Biology Department MS 50, Woods Hole Oceanographic Institution, Woods Hole, Massachusetts 02543, USA
}

\begin{abstract}
We quantified the relative contributions of water and food to strontium ( $\mathrm{Sr}$ ) and barium (Ba) deposited in otoliths of juvenile mummichogs Fundulus heteroclitus. Fish were reared in seawater spiked with ${ }^{86} \mathrm{Sr}$ and ${ }^{137} \mathrm{Ba}$ significantly beyond natural values to obtain distinct isotopic signatures for water and food. Element abundances ( $\mathrm{Sr}: \mathrm{Ca}$ and $\mathrm{Ba}: \mathrm{Ca})$ and isotope ratios $\left({ }^{88} \mathrm{Sr}:{ }^{86} \mathrm{Sr}\right.$ and ${ }^{138} \mathrm{Ba}:{ }^{137} \mathrm{Ba}$ ) were quantified in water samples using solution-based inductively coupled plasmamass spectrometry (ICP-MS), and ${ }^{88} \mathrm{Sr}:{ }^{86} \mathrm{Sr}$ and ${ }^{138} \mathrm{Ba}:{ }^{137} \mathrm{Ba}$ ratios in otoliths were quantified using laser ablation ICP-MS. The relative contributions of water and food sources to otolith aragonite were assessed using a simple linear isotope mixing model. Water sources contributed $83 \%$ of $\mathrm{Sr}$ and $98 \%$ of Ba in otoliths formed in spiked seawater. Our results indicate that water chemistry is the dominant factor controlling the uptake of $\mathrm{Sr}$ and $\mathrm{Ba}$ in the otoliths of marine fishes. Thus, chemical signatures recorded in the otoliths of marine fishes should reflect the ambient water composition of these elements at the time of deposition.
\end{abstract}

KEY WORDS: Otolith $\cdot$ Element uptake $\cdot$ Sr isotope $\cdot$ Ba isotope $\cdot$ Water sources

\section{INTRODUCTION}

Over the last century, fish otoliths (ear stones) have been used to study a wide array of topics in fish biology. Otoliths form by the periodic deposition of daily and annual increments, which allow researchers to determine ages and growth rates of individuals (Campana \& Nielson 1985, Dwyer et al. 2003). More recently, geochemical analyses of otoliths, often targeting specific growth increments, have been used to reconstruct thermal histories (Patterson et al. 1993, Gao \& Beamish 2003), identify fisheries management units (Edmonds et al. 1989, Rooker et al. 2003) and determine migration pathways (Limburg 1995, Secor et al. 2001, Thorrold et al. 2001).

Several properties of otoliths make them useful and reliable tools. First, they grow throughout the life of a fish by the addition of successive layers of aragonitic calcium carbonate (Campana 1999). These layers are often manifested as daily or yearly increments, and therefore otoliths may act as biological chronometers recording the age and growth rates of individual fish. Second, otoliths are acellular and metabolically inert and thus are not subject to resorption after the calcareous material accretes (Campana \& Nielson 1985). As a result, the chemical composition of a given layer remains constant over time. These properties allow the environmental history of a fish to be reconstructed by analyzing sections of an otolith corresponding to the time periods of interest.

Although studies involving otolith geochemistry are increasingly prevalent (Campana \& Thorrold 2001), few investigators have examined the sources of material deposited in otolith aragonite. Cations enter the blood plasma either through intestinal digestion or by transport across the branchial membranes (Campana 1999). These ions travel via the bloodstream to the inner ear and then across a membrane into the endolymph, where they are available for crystallization. Otolith composition will, therefore, reflect the relative contribution of water and dietary sources to the ions that ultimately precipitate out of solution at the depositional surface of the otolith. The distinction between 
water and diet is important because we would only expect otolith chemistry to reflect dissolved concentrations in the environment if water were the primary source of ions in the otoliths.

Traditionally, water was thought to contribute most to the composition of calcareous structures in teleosts (Schiffman 1961, Berg 1968, Simkiss 1974, Hoff \& Fuiman 1995, Farrell \& Campana 1996, Gallahar \& Kingsford 1996). However, dietary composition may also influence otolith chemistry. The elemental composition of otoliths has been shown to reflect diet in both freshwater (Limburg 1995, Kennedy et al. 2000) and marine (Buckel et al. 2004) fishes. We sought to address these discrepancies by rearing juvenile mummichogs Fundulus heteroclitus in seawater spiked with enriched $\mathrm{Sr}$ and $\mathrm{Ba}$ isotopes beyond the natural isotope ratios found in food. This experimental approach provided a definitive test of the relative contributions of water and diet to otolith composition.

\section{MATERIALS AND METHODS}

Fish-rearing conditions. Mummichogs are estuarine killifish that occupy marsh habitats along the east coast of North America from Florida to Newfoundland (Collette \& Klein-MacPhee 2002). Individuals were collected from Eel Pond in Woods Hole, Massachusetts, using baited minnow traps set during spring tides in June 2002. Eggs were manually extracted from gravid females and fertilized in vitro by commingling eggs and diced testes from sacrificed males in Petri dishes containing filtered natural seawater. The pieces of testes were removed after $24 \mathrm{~h}$. Eggs developed in Petri dishes at a room temperature of $19^{\circ} \mathrm{C}$ and seawater was changed every $3 \mathrm{~d}$. Eggs hatched after approximately $28 \mathrm{~d}$ and the larvae were then transferred to experimental tanks.

High-density polyethylene tanks were filled with $10 \mathrm{l}$ filtered natural seawater at a salinity of 30 (PSU). Replicate control tanks contained unaltered seawater, while treatment tanks were spiked with $1 \mathrm{mg}{ }^{86} \mathrm{Sr}$ and $50 \mu \mathrm{g}$ ${ }^{137} \mathrm{Ba}$ each. Stable isotopes were purchased from Oak Ridge National Laboratory, Tennessee, USA. After treatment tanks were spiked, 10 fish were added to each tank, except for 1 control tank that contained only 9 fish. All fish were fed daily on TetraColor ${ }^{\text {TM }}$ Tropical Flakes for the first $28 \mathrm{~d}$ and subsequently twice daily until harvest. Tanks were covered to minimize evaporation, and were maintained at a constant room temperature of $19^{\circ} \mathrm{C}$ under a $14 \mathrm{~h} \mathrm{light:10} \mathrm{h}$ dark cycle. Despite a constant internal filtration system, food accumulated on the bottom of the tanks. To maintain water quality, we changed one-third of the water volume weekly $26 \mathrm{~d}$ into the experiment. Water added to the treatment tanks was spiked with ${ }^{86} \mathrm{Sr}$ and ${ }^{137} \mathrm{Ba}$ to maintain constant treatment ratios throughout the experiment. Fish were harvested and frozen after $70 \mathrm{~d}$. High mortality rates in 3 of the tanks meant that we were only able to harvest fish from 3 treatment tanks and 1 control tank (see Table 1).

Water sampling. Water samples were taken weekly from each tank with acid-washed polypropylene syringes. Samples were processed in a Class 100 clean room, where $10 \mathrm{ml}$ of water was filtered through $0.2 \mu \mathrm{m}$ acid-washed polypropylene filters, acidified with $200 \mu$ l of concentrated ultrapure $\mathrm{HNO}_{3}$, and then refrigerated at $5^{\circ} \mathrm{C}$. Immediately before analysis samples were returned to room temperature, diluted 50:1 with $2 \%$ ultrapure $\mathrm{HNO}_{3}$, and spiked with ${ }^{115} \mathrm{In}$ at $1 \mathrm{ng} \mathrm{g}^{-1}$ for use as an internal standard.

All samples were run on a Finnigan MAT Element ICP-MS using a self-aspirating $50 \mu \mathrm{min}^{-1}$ PFA nebulizer attached to a quartz cyclonic spray chamber. Concentrations of $\mathrm{Ca}_{1} \mathrm{Sr}$ and $\mathrm{Ba}$ were quantified by monitoring ${ }^{43} \mathrm{Ca},{ }^{88} \mathrm{Sr}$ and ${ }^{138} \mathrm{Ba}$ at low resolution, and then standardizing blank-corrected isotope intensities to ${ }^{115}$ In following the method of Field et al. (1999). Element concentrations were expressed as molar ratios to $\mathrm{Ca}$ since $\mathrm{Sr}$ and $\mathrm{Ba}$ in otoliths vary as a function of element:Ca ratios rather than of absolute concentration (Bath et al. 2000, Kraus \& Secor 2004). Estimates of analytical precision (relative standard deviation) of a reference seawater run at intervals throughout the analyses ( $\mathrm{n}=4$ ) were $3.5 \%$ for $\mathrm{Sr}: \mathrm{Ca}$ and $4.5 \%$ for Ba:Ca.

Isotope ratios of $\mathrm{Sr}$ and $\mathrm{Ba}$ were measured in the water samples using the same sample-introduction system and diluted solutions that were assayed for element concentrations. We measured ${ }^{86} \mathrm{Sr},{ }^{88} \mathrm{Sr},{ }^{137} \mathrm{Ba}$ and

${ }^{138} \mathrm{Ba}$ in water samples, the seawater standard and $2 \%$ $\mathrm{HNO}_{3}$ blanks. Isotope ratios $\left({ }^{88} \mathrm{Sr}:{ }^{86} \mathrm{Sr}\right.$ and $\left.{ }^{138} \mathrm{Ba}:{ }^{137} \mathrm{Ba}\right)$ were then calculated from blank-corrected abundances following correction for instrument mass bias, assuming that natural isotope ratios $\left({ }^{88} \mathrm{Sr}:{ }^{86} \mathrm{Sr}=8.375\right.$ and ${ }^{138} \mathrm{Ba}:{ }^{137} \mathrm{Ba}=6.385$ ) were present in the seawater standard.

Otolith chemistry. Sagittal otolith pairs were removed from each fish and cleaned of tissue. We randomly selected 1 otolith from each pair and mounted it on a petrographic slide with cyanoacrylic glue. Mounted otoliths were ground to the midplane on $3 \mu \mathrm{m}$ lapping film. Otoliths were immersed in ultrapure Milli-Q water, left to soak for $24 \mathrm{~h}$, and then sonicated for $2 \mathrm{~min}$ to remove surface contamination. After a triple-rinse, otoliths were left to dry in a class 100 laminar flow hood for $24 \mathrm{~h}$. Once dry, the otoliths were remounted on slides using double-sided tape for $\mathrm{Sr}$ and $\mathrm{Ba}$ isotope analyses.

Isotope ratios of $\mathrm{Sr}$ and $\mathrm{Ba}$ in each otolith were quantified with a New Wave Research UP213 laser ablation 
system coupled to a Thermo Finnigan Element ICPMS. The instrument set-up was similar to that outlined by Günther \& Heinrich (1999) as modified by FitzGerald et al. (2004). Briefly, an He gas stream was used to carry ablated material from the laser cell to the ICPMS. The carrier gas was then mixed with the Ar sample gas and a wet aerosol $\left(2 \% \mathrm{HNO}_{3}\right)$ in the concentric region of the quartz dual inlet spray chamber. The wet aerosol was supplied by a self-aspirating PFA microflow $\left(20 \mu \mathrm{m} \mathrm{min}^{-1}\right)$ nebulizer attached to a CETAC ASX100 autosampler. The laser software was used to trace a $150 \times 150 \mu \mathrm{m}$ raster near the edge of the otoliths that consisted of material laid down during the experimental period. Blank-corrected isotope abundances were corrected for instrument mass bias using an otolith reference material (Yoshinaga et al. 2000) that was dissolved in $2 \% \mathrm{HNO}_{3}$ and diluted to a final $\mathrm{Ca}$ concentration of $40 \mathrm{\mu g} \mathrm{g}^{-1}$. As with the seawater standard, we assumed that the otolith reference material contained natural isotope ratios for both ${ }^{88} \mathrm{Sr}:{ }^{86} \mathrm{Sr}$ and ${ }^{138} \mathrm{Ba}:{ }^{137} \mathrm{Ba}$. Precision of the technique was assessed by assaying ${ }^{88} \mathrm{Sr}:{ }^{86} \mathrm{Sr}$ and ${ }^{138} \mathrm{Ba}:{ }^{137} \mathrm{Ba}$ ratios in the aragonitic skeleton of a marine sclerosponge at regular intervals throughout the otolith analyses. Calculated values from the sclerosponge $\left({ }^{88} \mathrm{Sr}:{ }^{86} \mathrm{Sr}=8.33 \pm 0.1[1 \mathrm{SD}]\right.$, ${ }^{138} \mathrm{Ba}:{ }^{137} \mathrm{Ba}=6.43 \pm 0.03[1 \mathrm{SD}], \mathrm{n}=6$ ) were within $2 \mathrm{SD}$ of natural values for the $\mathrm{Sr}$ and $\mathrm{Ba}$ isotope ratios.

Finally, the percent contribution of the water to $\mathrm{Sr}$ and Ba deposited in the otoliths during the experiment was calculated with a mixing model following Kennedy et al. (2000):

$$
\begin{aligned}
& \% \text { element }_{\text {(from water) }}= \\
& {\left[1-\left(\frac{\text { isotope ratio }_{\text {water }}-\text { isotope ratio }_{\text {otolith }}}{\text { isotope ratio }_{\text {water }}-\text { isotope ratio }_{\text {natural }}}\right)\right] \times 100}
\end{aligned}
$$

Isotope ratios for the water used in this model were an average of samples taken from each spiked tank over the course of the experiment. This calculation assumed that the food contains natural isotope ratios $\left({ }^{88} \mathrm{Sr}:{ }^{86} \mathrm{Sr}=8.375\right.$ and $\left.{ }^{138} \mathrm{Ba}:{ }^{137} \mathrm{Ba}=6.385\right)$ because these ratios are invariant in nature (Lide 1995). The contribution of food to otolith aragonite was then calculated as:

$$
\% \text { element }_{(\text {from food) }}=100-\left(\% \text { element }_{\text {(from water })}\right)
$$

\section{RESULTS}

\section{Water chemistry}

Element concentrations within the rearing tanks varied between 8.5 and $9.3 \mathrm{mmol} \mathrm{mol}^{-1}$ for $\mathrm{Sr}: \mathrm{Ca}$ and between 10 and $37 \mu \mathrm{mol} \mathrm{mol}{ }^{-1}$ for Ba:Ca (Fig. 1). These changes presumably reflected chemistry differences in
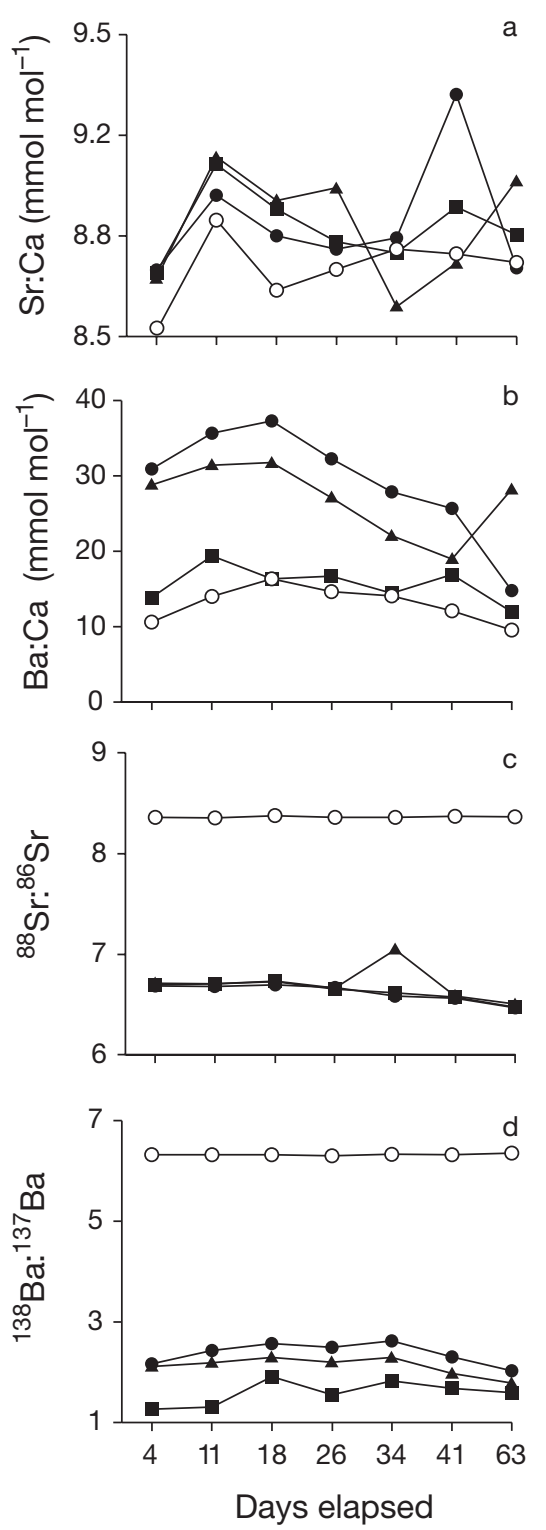

Fig. 1. $(\mathrm{a}, \mathrm{b})$ Element $(\mathrm{Sr}: \mathrm{Ca}$ and $\mathrm{Ba}: \mathrm{Ca})$ ratios and $(\mathrm{c}, \mathrm{d})$ isotope ratios $\left({ }^{88} \mathrm{Sr}:{ }^{86} \mathrm{Sr}\right.$ and $\left.{ }^{138} \mathrm{Ba}:{ }^{137} \mathrm{Ba}\right)$ in water samples taken during course of the experiment from 3 treatment tanks spiked with enriched ${ }^{86} \mathrm{Sr}$ and ${ }^{137} \mathrm{Ba}$ (filled symbols) and control tank with natural isotope ratios (open symbols)

the seawater supply line from which replacement water was taken during the experiment. Isotope ratios within the tanks during the experiment were, however, more constant (Fig. 1). The 3 spiked tanks had ${ }^{88} \mathrm{Sr}:{ }^{86} \mathrm{Sr}$ ratios of $6.64 \pm 0.09,6.62 \pm 0.09$ and $6.7 \pm 0.2$ $(\mathrm{SD})$, and ${ }^{138} \mathrm{Ba}:{ }^{137} \mathrm{Ba}$ ratios of $1.6 \pm 0.3,2.1 \pm 0.2$ and 2.4 \pm 0.2 (SD). As expected, there was little variation in isotope ratios within the control tank during the experiment, with mean values for both ${ }^{88} \mathrm{Sr}:{ }^{86} \mathrm{Sr}(8.376 \pm$ $0.007)$ and ${ }^{138} \mathrm{Ba}:{ }^{137} \mathrm{Ba}(6.359 \pm 0.014)$ being within $2 \mathrm{SD}$ 
of natural ratios. Although fish mortality precluded the inclusion of multiple control tanks, little variability among control tanks in isotope ratios would be expected since natural ratios are constant (Lide 1995).

\section{Isotope ratios in otoliths}

Both ${ }^{88} \mathrm{Sr}:{ }^{86} \mathrm{Sr}$ and ${ }^{138} \mathrm{Ba}:{ }^{137} \mathrm{Ba}$ ratios in otoliths of fish from the control tank were within $2 \mathrm{SD}$ of natural ratios of these isotopes in the environment (Table 1). However, isotope ratios of otoliths from fish from the treatment tanks were significantly more enriched in both ${ }^{86} \mathrm{Sr}$ and ${ }^{137} \mathrm{Ba}$ over natural levels, indicating a significant contribution of water to otolith chemistry. We calculated the percent contributions of water and diet to $\mathrm{Sr}$ and $\mathrm{Ba}$ in the otoliths using a simple mixing-model between the natural ratios of ${ }^{88} \mathrm{Sr}:{ }^{86} \mathrm{Sr}$ and ${ }^{138} \mathrm{Ba}:{ }^{137} \mathrm{Ba}$ found in the diet and the altered ratios measured in each of the rearing tanks (Table 1). Based on the model, water contributed $83 \pm 6$ (SD) $\%$ to $\mathrm{Sr}$ and $98 \pm 3$ (SD) \% to $\mathrm{Ba}$ in the otoliths of the experimental fish, averaged over treatment tanks. Consequently, food only contributed approximately $17 \%$ of $\mathrm{Sr}$ and $2 \%$ of Ba to otolith aragonite.

\section{DISCUSSION}

Our study used a novel technique to investigate sources of 2 alkali earth metals ( $\mathrm{Sr}$ and $\mathrm{Ba}$ ) incorporated into the aragonitic otoliths of a marine fish. We reared fish in seawater that was spiked with stable isotopes of $\mathrm{Sr}$ and Ba beyond any natural variation in the environment. The presence of unique isotope signatures in the water enabled us to use a simple mixing model to determine the relative contributions of water and food to the $\mathrm{Sr}$ and $\mathrm{Ba}$ ions deposited in otoliths of the larval fish during the experiment. Isotope ratios of food sources were not directly measured in this experiment but the food sources must have contained natural isotope ratios of both ${ }^{88} \mathrm{Sr}:{ }^{86} \mathrm{Sr}$ and ${ }^{138} \mathrm{Ba}:{ }^{137} \mathrm{Ba}$, since these ratios are invariant in nature (Lide 1995). The results demonstrated that $\mathrm{Sr}$ and Ba in the otoliths were derived primarily from the ambient water. Over $80 \%$ of otolith $\mathrm{Sr}$ and more than $95 \%$ of otolith Ba originated from the water in which the fish were reared.

The finding that water contributes most of the $\mathrm{Sr}$ and Ba ions ultimately deposited in otoliths is significant for studies that attempt to relate otolith chemistry to that of the ambient environment experienced by individual fish (Campana 1999). Were food to contribute the majority of otolith $\mathrm{Sr}$ and $\mathrm{Ba}$, then otolith composition could be decoupled from element concentrations in the surrounding water. However, our results suggest that $\mathrm{Sr}$ and $\mathrm{Ba}$ in otoliths are likely to be sensitive to changes in ambient levels in the environment. Indeed, these data complement the results of studies that have documented significant correlations between otolith composition and the concentrations of several elements in ambient waters (Bath et al. 2000, Milton \& Chenery 2001, Elsdon \& Gillanders 2002).

Previous workers have produced conflicting results concerning the relative importance of diet to otolith elemental composition (e.g. Farrell \& Campana 1996, Kennedy et al. 2000). The research may be usefully divided into studies that have manipulated the elemental composition of diets and studies that have used isotope variations to quantify the relative contribution of water and diet to otolith composition. In those studies that altered dietary intake of elements, several authors reported no influence of diet (Hoff \& Fuiman 1995, Milton \& Chenery 2001), while others found detectable effects of diet on otolith chemistry (Limburg 1995, Gallahar \& Kingsford 1996, Buckel et al. 2004). Of the studies that reported detectable dietary effects on otolith chemistry, Limburg (1995) and Gallahar \& Kingsford (1996) found small effects on otolith Sr content when fish were fed Sr-spiked food. Buckel et al. (2004), however, reported that Sr increased by approximately $20 \%$ and Ba increased by $100 \%$ in otoliths of juvenile bluefish fed prey that differed in $\mathrm{Sr}$ and $\mathrm{Ba}$ concentration by approximately $250 \%$. Unfortunately, Buckel et al. (2004) measured neither water chemistry

Table 1. Isotope ratios (mean $\pm \mathrm{SD}$ ) in water $\left(\mathrm{H}_{2} \mathrm{O}\right)$ and otoliths (oto) from rearing tanks containing seawater spiked with ${ }^{86} \mathrm{Sr}$ and ${ }^{137} \mathrm{Ba}$ (Tanks 1, 2 and 3) and a control tank. Water values are averages of 7 samples taken during the course of the experiment; $\mathrm{n}$ : number of surviving fish in each tank that were used for otolith analyses. Percent contribution of water $\left(\% \mathrm{H}_{2} \mathrm{O}\right)$ to $\mathrm{Sr}$ and $\mathrm{Ba}$ in otoliths of fish from each spiked tank was calculated from a linear mixing model

\begin{tabular}{|c|c|c|c|c|c|c|c|}
\hline \multirow{2}{*}{ Tank } & \multirow[t]{2}{*}{$\mathrm{n}$} & \multicolumn{3}{|c|}{$\mathrm{Sr}$} & \multirow[b]{2}{*}[{}^{137/138}\mathrm{Ba}]{$_{\mathrm{H}_{2}} \mathrm{O}$} & \multicolumn{2}{|l|}{ - $\mathrm{Ba}$} \\
\hline & & {$\left[{ }^{88 / 86} \mathrm{Sr}\right]_{\mathrm{H}_{2} \mathrm{O}}$} & {$\left[{ }^{88 / 86} \mathrm{Sr}\right]_{\text {oto }}$} & $\% \mathrm{H}_{2} \mathrm{O}$ & & {$\left[{ }^{137 / 138} \mathrm{Ba}\right]_{\text {oto }}$} & $\% \mathrm{H}_{2} \mathrm{O}$ \\
\hline 1 & 1 & $6.64 \pm 0.09$ & 7.06 & 76 & $1.59 \pm 0.25$ & 1.55 & 101 \\
\hline 2 & 3 & $6.62 \pm 0.09$ & $6.9 \pm 0.3$ & 86 & $2.38 \pm 0.22$ & $2.55 \pm 0.01$ & 96 \\
\hline 3 & 9 & $6.71 \pm 0.17$ & $6.9 \pm 0.2$ & 86 & $2.12 \pm 0.19$ & $2.29 \pm 0.15$ & 96 \\
\hline Control & 4 & $8.38 \pm 0.01$ & $8.3 \pm 0.1$ & - & $6.36 \pm 0.01$ & $6.42 \pm 0.02$ & - \\
\hline
\end{tabular}


nor the Ca concentration of the prey items in their experiment. Nonetheless, assuming that Ca concentrations were similar in both prey types, from the data of Buckel et al. (2004) we calculated that water probably contributed approximately $70 \%$ of the Sr and $40 \%$ of the $\mathrm{Ba}$ deposited in the otoliths of juvenile bluefish in their study. Clearly, more experimentation is needed to ascertain if the differences between the results reported here and those of Buckel et al. (2004) are due to interspecific variability, salinity effects (juvenile bluefish were reared at $\sim 23$, juvenile mummichogs at 30 PSU), or some artifact of one of the experimental approaches.

Researchers using isotopic techniques to examine dietary effects on otolith chemistry have addressed the issue by directly measuring the relative contribution of water and food to the ions that are ultimately deposited in otoliths. Farrell \& Campana (1996) quantified the relative contributions of water and food to otolith composition using radio-labeled $\mathrm{Ca}$ and $\mathrm{Sr}$ isotopes and found $75 \%$ of $\mathrm{Ca}$ and $88 \%$ of $\mathrm{Sr}$ in otoliths of freshwater Nile tilapia derived from the water. In contrast, based on natural isotope variations in water and food Kennedy et al. (2000) reported that $70 \%$ of $\mathrm{Sr}$ in otoliths of Atlantic salmon reared in freshwater environments originated from dietary sources. While conclusions about the relative contributions of water and food to otoliths of freshwater fishes remain ambiguous, the present study used isotopic techniques to demonstrate that marine fish depend primarily on water sources for $\mathrm{Sr}$ and $\mathrm{Ba}$ accreted in otoliths.

If fishes rely on ambient water as their primary source for otolith material, then $\mathrm{Sr}$ and $\mathrm{Ba}$ isotope ratios in the otolith should reflect those of the water column. Both $\mathrm{Sr}$ and Ba substitute easily for $\mathrm{Ca}$ ions in the aragonitic matrix, since they exhibit ionic radii similar to Ca (Speer 1983). In addition, they are nonessential elements for fishes and undergo less direct regulation at interfaces along the pathway to accretion compared to essential elements such as $\mathrm{Na}$ and $\mathrm{Ca}$ (Campana 1999). The relative importance of water and dietary sources to the otoliths may change depending on Ca availability in the water column (Berg 1968, Farrell \& Campana 1996). Because Ca concentration varies with salinity, freshwater fishes may compensate for decreased water-Ca by deriving relatively more ions from their food. In order to fully understand variations in the importance of water and food sources to otolith formation, experiments testing the link between salinity and dietary contribution are needed to determine whether freshwater fishes rely more on food sources for otolith material than marine fishes. However, our evidence shows that marine fishes do indeed draw primarily upon water sources for non-essential minor and trace elements incorporated into otoliths.
Acknowledgements. We thank D. Schneider of the ICP-MS Facility at WHOI for assistance in analyzing otoliths and water samples, B. Woodin for advice on capturing and hatching mummichogs, and 2 anonymous reviewers for their comments. This work was funded by NSF grant OCE-0134998 to S.R.T.

\section{LITERATURE CITED}

Bath GE, Thorrold SR, Jones CM, Campana SE, McLaren JW, Lam JWH (2000) Strontium and barium uptake in aragonitic otoliths of marine fish. Geochim Cosmochim Acta 64: 1705-1714

Berg A (1968) Studies on the metabolism of calcium and strontium in freshwater fish. I. Relative contribution of direct and intestinal absorption. Mem Ist Ital Idrobiol Dott Marco Marchi 23:161-196

Buckel JA, Sharack BL, Zdanowicz VS (2004) Effect of diet on otolith composition in Pomatomus saltatrix, an estuarine piscivore. J Fish Biol 64:1469-1484

Campana SE (1999) Chemistry and composition of fish otoliths: pathways, mechanisms and applications. Mar Ecol Prog Ser 188:263-297

Campana SE, Nielson JD (1985) Microstructure of fish otoliths. Can J Fish Aquat Sci 42:1014-1032

Campana SE, Thorrold SR (2001) Otoliths, increments, and elements: keys to a comprehensive understanding of fish populations? Can J Fish Aquat Sci 58:30-38

Collette BB, Klein-MacPhee G (2002) Bigelow and Schroeder's fishes of the Gulf of Maine. Smithsonian Institution Press, Washington, DC

Dwyer K, Walsh S, Campana S (2003) Age determination, validation and growth of Grand Bank yellowtail flounder (Limanda ferruginea). ICES J Mar Sci 60:1123-1138

Edmonds JS, Moran MJ, Caputi N, Morita M (1989) Trace element analysis of fish sagittae as an aid to stock identification: pink snapper (Chrysophrys auratus) in Western Australia waters. Can J Fish Aquat Sci 46:50-54

Elsdon TS, Gillanders BM (2002) Interactive effects of temperature and salinity on otolith chemistry: challenges for determining environmental histories of fish. Can J Fish Aquat Sci 59:1796-1808

Farrell J, Campana SE (1996) Regulation of calcium and strontium deposition on the otoliths of juvenile tilapia, Oreochromis niloticus. Comp Biochem Physiol A 115:103-109

Field MP, Cullen JT, Sherrell RM (1999) Direct determination of 10 trace metals in $50 \mu \mathrm{l}$ samples of coastal seawater using desolvating micronebulization sector field ICP-MS. J Anal At Spectrom 14:1425-1431

FitzGerald JL, Thorrold SR, Bailey KM, Brown AL, Severin KP (2004) Elemental signatures in otoliths of larval walleye pollock (Theragra chalcogramma) from the northeast Pacific Ocean. Fish Bull (Wash DC) 102:604-616

Gallahar NK, Kingsford MJ (1996) Factors influencing Sr/Ca ratios in otoliths of Girella elevata: an experimental investigation. J Fish Biol 48:174-186

Gao Y, Beamish RJ (2003) Stable isotope variations in otoliths of Pacific halibut (Hippoglossus stenolepis) and indications of the possible 1990 regime shift. Fish Res 60:393-404

Günther D, Heinrich CA (1999) Enhanced sensitivity in laser ablation-ICP mass spectrometry using helium-argon mixtures as aerosol carrier-plenary lecture. J Anal At Spectrom 14:1363-1368

Hoff GR, Fuiman LA (1995) Environmentally-induced variation in elemental composition of red drum (Sciaenops ocellatus) otoliths. Bull Mar Sci 56:578-591 
Kennedy BP, Blum JD, Folt CL, Nislow KH (2000) Using natural strontium isotopic signatures as fish markers: methodology and application. Can J Fish Aquat Sci 57:2280-2292

Kraus RT, Secor DH (2004) Incorporation of strontium into otoliths of an estuarine fish. J Exp Mar Biol Ecol 302: 85-106

Lide DR (ed) (1995) CRC handbook of chemistry and physics. CRC Press, Boca Raton, FL

Limburg KE (1995) Otolith strontium traces environmental history of subyearling American shad Alosa sapidissima. Mar Ecol Prog Ser 119:25-35

Milton DA, Chenery SR (2001) Sources and uptake of trace metals in otoliths of juvenile barramundi (Lates calcarifer). J Exp Mar Biol Ecol 264:47-65

Patterson WP, Smith GR and Lohmann KC (1993) Continental paleothermometry and seasonality using the isotopic composition of aragonitic otoliths of freshwater fishes. Geophys Monogr 78:191-202

Rooker JR, Secor DH, Zdanowicz VS, De Metrio G, Relini LO (2003) Identification of Atlantic bluefin tuna (Thunnus

Editorial responsibility: Otto Kinne (Editor-in-Chief), Oldendorf/Luhe, Germany thynnus) stocks from putative nurseries using otolith chemistry. Fish Oceanogr 12:75-84

Schiffman RH (1961) The uptake of strontium from diet and water by rainbow trout. Report No. HW-72107, Hanford Atomic Products Operation, Richland, WA

Secor DH, Rooker JR, Zlokovitz E and Zdanowicz VS (2001) Identification of riverine, estuarine, and coastal contingents of Hudson River striped bass based upon otolith elemental fingerprints. Mar Ecol Prog Ser 211:245-253

Simkiss K (1974) Calcium metabolism of fish in relation to ageing. In: Bagenal TB (ed) The ageing of fish. Unwin Brothers, Old Woking, p 1-12

Speer JA (1983) Crystal chemistry and phase relations of the orthorhombic carbonates. Rev Mineral 11:145-190

Thorrold SR, Latkoczy C, Swart PK, Jones CM (2001) Natal homing in a marine fish metapopulation. Science 291: 297-299

Yoshinaga J, Nakama A, Morita M, Edmonds JS (2000) Fish otolith reference material for quality assurance of chemical analyses. Mar Chem 69:91-97

Submitted: May 13, 2005; Accepted: September 2, 2005

Proofs received from author(s): February 21, 2006 